\title{
PERFORATED PEPTIC ULCERS: 3 YEAR EXPERIENCE IN KLAIPEDA UNIVERSITY HOSPITAL
}

\author{
Šarūnas Dailidėnas ${ }^{1}$, Martynas Garčauskis ${ }^{2}$, Gintarẻ Srèbaliūtė², Jonas Jurgaitis ${ }^{1}$, \\ Paulius Žeromskas ${ }^{1}$, Dainius Šimčikas ${ }^{1,3}$ \\ ${ }^{1}$ Klaipeda University Hospital, Abdominal and Endocrine Surgery Clinic, Klaipeda, Lithuania, \\ ${ }^{2}$ Lithuanian University of Health Sciences, Faculty of Medicine, \\ ${ }^{3}$ Klaipeda University, Faculty of Health Sciences, Klaipeda, Lithuania
}

Key words: perforated peptic ulcer

\section{Summary}

Perforation is second most common complication of peptic ulcers with mortality rate ranging from 3 to 30 $\%$. For best outcomes this condition must be diagnosed and managed as soon as possible.

Objectives and methods. The aim of this study was to present our clinical experience in managing perforated peptic ulcers. Retrospective data analysis of patients treated for perforated peptic ulcers from year 2015 to 2017 was performed. Statistical data analysis was carried out using the SPSS 20.0 software.

Results. 90 patients were treated for perforated peptic ulcers. The female and male ratio was 1:1.25 with the mean patient age of $61.60 \pm 19.42$ years. There were no more data from 16 patients. The average hospital stay was $12.89 \pm 13.31$ days. $11 \%$ of the patients had type I, 49\% - type II, 24\% - type III, 5\%- type IV, $11 \%$ - type $\mathrm{V}$ ulcer according to modified Johnson classification. $91 \%$ underwent ulcerorrhaphy, $4 \%$ Billroth type I surgery, 2\% - Billroth type II surgery and $1 \%$ had atypic resection. $84 \%$ of surgeries were performed with laparotomic approach, $12 \%$ - laparoscopically, $4 \%$ had a conversion. The mean duration of the operation was $85.2 \pm 4.64$ minutes. The average Mannheim Peritonitis Index between the patients was $17.135 \pm 7.36 .24 \%$ of patients with perforated peptic ulcer died. Statistically significant correlation was observed between the Mannheim Peritonitis Index and mortality $(\mathrm{r}=0.640 ; \mathrm{p}<0.05)$, age and mortality $(\mathrm{r}=0.459 ; \mathrm{p}<0.05)$ and between age and Mannheim Peritonitis Index $(r=0.740 ; p<0.05)$.

Conclusion. During the period from 2015 to 201790 patients were treated for PPU. Half of the patients had type II ulcer localization according to modified Johnson classification. Simple closure was performed for $91 \%$ of the patients, $84 \%$ of all surgeries were performed with an open approach. Statistically significant correlation was found between Mannheim Peritonitis Index and mortality, age and mortality and between age and Mannheim Peritonitis Index. No significant correlation was observed between the approach and the outcome. There could be a bigger role in laparascopic surgery treating PPU. It is important for clinicists to consider about PPI for treatment when prescribing NSAIDs, especially in elderly and hospitalized patients in order to avoid peptic ulcers and its complications.

\section{Introduction}

A peptic ulcer is a defect in the gastric or duodenal mucosa that penetrates into the deeper layers of the wall which appears when balance between protective mechanisms and gastric acid secretion is corrupted. Most common complications of peptic ulcer disease include bleeding, perforation, penetration and gastric outlet obstruction.

Risk factors for developing peptic ulcer complications include nonsteroidal anti-inflammatory drug or acetylsalicylic acid use, Helicobacter pylori infection and ulcer size being greater than $1 \mathrm{~cm}$ [1]. Most patients with peptic ulcer disease are elderly and with co-morbidities and usually taking NSAIDs or acetylsalicylic acid, meaning they are more prone to all the complications and are associated with higher mortality rate [2]. According to Spanish study, NSAID are the only factor significantly associated with perforation [3].

In the United states perforation (9\%) is the second most common complication after haemorrhage (73\%). Nevertheless, perforation has the highest mortality rate (3-30 \%) compared to other complications [2]. Average 30-day mortality 
after perforation is about $23,5 \%$ [4]. The average long-term recurrence rate of peptic ulcer perforation is $12,1 \%$ [1].

Modified Johnson classification classifies peptic ulcers by localization into five types: I - in the body of the stomach along lesser curve at incisura angularis, II -in the body in combination with duodenal ulcers, III - in the pyloric channel within $3 \mathrm{~cm}$ of pylorus, IV - proximal gastroesophageal ulcer, V - can occur throughout the stomach, associated with chronic use of NSAIDs.

Most common symptom of perforated peptic ulcer (PPU) is sudden, severe abdominal pain, usually located in epigastric region of the abdomen, followed by nausea, vomiting, abdominal distention [5]. Since the course of disease progresses rapidly diagnosis should be made as soon as possible and adequate treatment should be administered.

During clinical evaluation it is important to consider other diseases that present similar symptoms such as acute pancreatitis or ruptured abdominal aortic aneurysm. Laboratory markers are non-specific for perforated ulcer, nevertheless, they provide information about inflammatory response and organ function, therefore, helping to exclude other diseases. Since perforated peptic ulcer is one of the most common cause of pneumoperitoneum, radiological imaging may be diagnostic. Although an abdominal x-ray is fast and cheap, abdominal computed tomography is considered to be the gold standard for its high sensitivity and additional value for excluding other diagnoses [2]. As soon as diagnosed, antibiotics should be administered [6].

Surgical method of treatment and approach depends on site of perforation, size, time since first clinical symptoms, general state of patient and experience of surgeon. During the operation, biopsy should always be taken in order to exclude

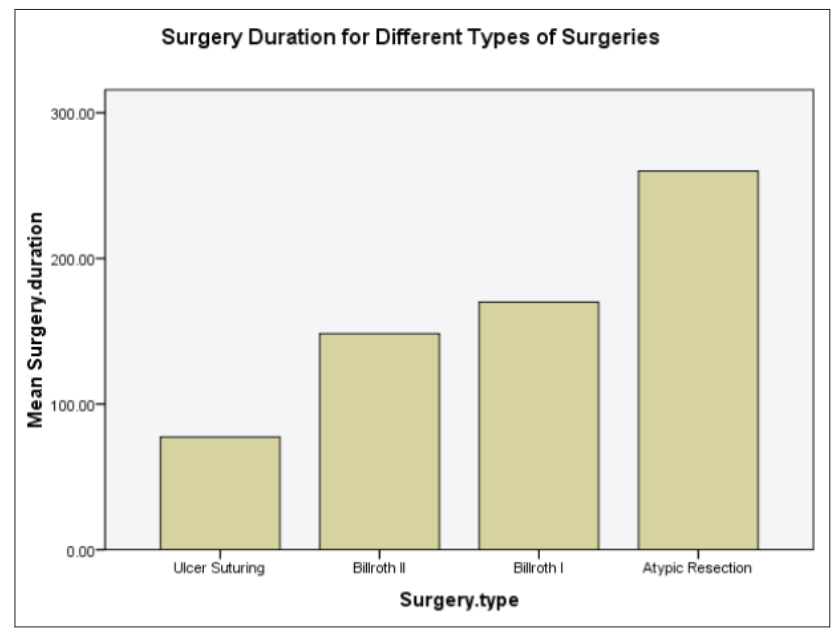

Pic. 1. malignancy. Etiopathogenic surgical treatment options such as vagotomy and gastric resection (Billroth type I, II operations) is no longer used so common since the introduction of proton-pump inhibitors (PPI). The main surgical treatment for perforated peptic ulcer is considered to be ulcerorrhapy with or without additional patch of omentum covering the perforation (Graham patch) [6].

In our country some hospitals approach PPU treatment using pyloroplasty type HOLLE classification, which is graded 1 to 5 , referring from simple ulcerorraphy to complete Billroth type 1 surgery.Several studies have found significant difference between operating times with simple closure being faster. Nevertheless, no significant difference has been observed between the outcomes, meaning both operations are equally safe $[7,8]$.

All mentioned procedures may be performed with laparoscopic and open approach. Although, open operations are faster to perform compared to laparoscopic, several studies found no significant difference in mortality, postoperative complications or length of hospital stay between both approaches. This demonstrates that laparoscopic method is safe and equally effective $[2,9,10]$.

Helicobacter pylori eradication after surgery must be considered as it reduces the recurrence of the ulcer. PPI reduce the risk of complications in patients with peptic ulcer disease and should be recommended to use daily after the surgery [6].

The aim of this study was to present our clinical experience in managing perforated peptic ulcers.

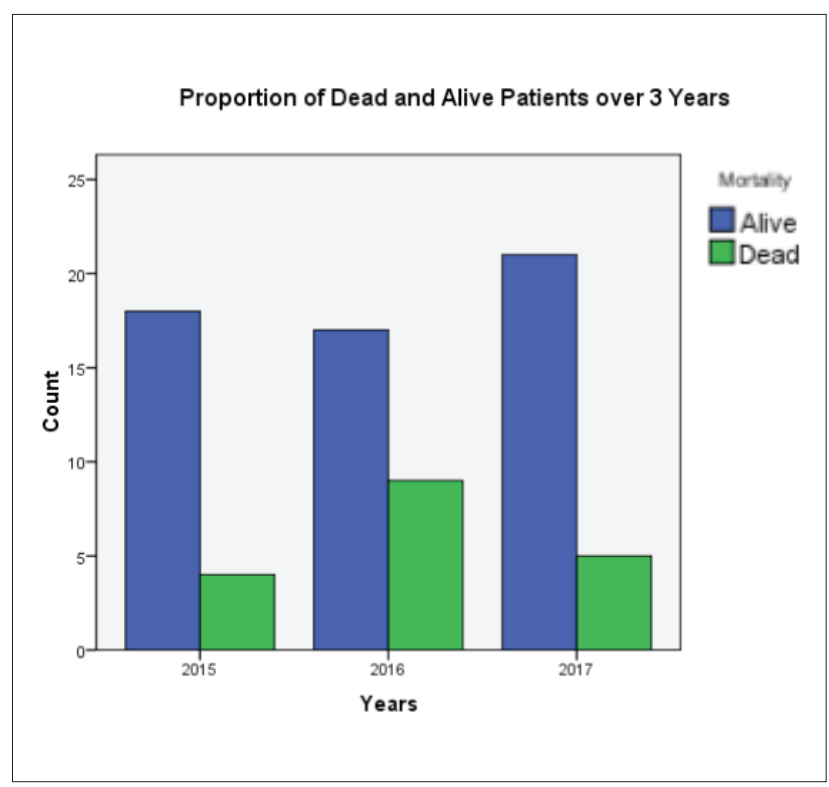

Pic. 2. 


\section{Objectives and methods}

Medical records of 90 patients who were diagnosed with perforated peptic ulcer from January 2015 through December 2017 at Klaipeda university hospital were retrospectively reviewed. The aim of this study was to present our clinical experience regarding peptic ulcer perforation. We retrospectively collected the clinical data including sex, age, hospitalization length, location of ulcer using modified Johnson classification, surgery type, surgical approach, duration of the operation. Mannheim peritonitis index was calculated. Correlation between clinical features, outcomes and mortality were calculated. In this study, a P value $<0.05$ was considered as statistically significant for all tests. Statistical analysis was performed using SPSS version 20.0.

\section{Results}

During the period from year 2015 to 2017 in Klaipeda University Hospital 90 patients were treated for perforated gastric or duodenal ulcers. Demographic statistics showed that female $(\mathrm{n}=40)$ and male $(\mathrm{n}=50)$ ratio was $1: 1.25$ while the mean patient age was $61.60 \pm 19.42$ years. There were no more data from 16 patients. Admissions due to perforation remained relatively constant during this period: 22 patients were admitted to hospital in 2015, 26 in 2016 and 2017. The average hospital stay of the remaining patients $(\mathrm{n}=74)$ was $12.89 \pm 13.31$ days. According to the modified Johnson classification of peptic ulcer $11 \%$ of the patients $(n=8)$ had type I, $49 \%(\mathrm{n}=36)$ - type II, $24 \%(\mathrm{n}=18)$ - type III, $5 \%$ $(n=4)$ - type IV, $11 \%(n=8)$ - type V.

Majority of the patients - $91 \%$ underwent ulcerorrhaphy, 4\% - Billroth type I surgery, 2\% - Billroth type II surgery and $1 \%$ had atypic resection. $84 \%$ of surgeries were performed with laparotomic approach, 12\% - laparoscopically, $4 \%$ had a conversion. The mean duration of the operation was $85.2 \pm 4.64$ minutes (picture 1). The average Mannheim Peritonitis Index between the patients was 17.135 7.36. 24\% of patients with perforated gastric or duodenal ulcer died.

There was no statistically significant correlation between surgical treatment method and outcome $(r=0.518 ; \mathrm{p}=0.179)$. Statistically significant correlation was observed between the Mannheim Peritonitis Index and mortality $(r=0.640 ; p<0.05)$, age and mortality $(\mathrm{r}=0.459 ; \mathrm{p}<0.05)$ and between age and Mannheim Peritonitis Index $(r=0.740 ; \mathrm{p}<0.05)$. This indicates that Mannheim Peritonitis index and patient age affected patients state of health, while surgical method of treatment and approach did not affect the outcome.

\section{Discussion}

In our study, incidence of perforated peptic ulcer each year and age of patients remains relatively stable as well as in other countries [2]. Greater incidence is observed in male patients. Male patients with PPU tend to be younger, since there is higher frequency of risk factors in this population, such as smoking, alcohol consumption and also men have shorter life span compared to women, in spite of that, women usually have more comorbidities, which leads to worse outcomes [11].

Similar studies conducted in Romania, India, Southern Asia, Middle East and Arab countries revealed that rates of PPU are greater in males and most common localization is found to be duodenal [2,12-14]. Type V ulcer localization is associated with the use of NSAIDs.Due to possible inaccurate documentation of NSAIDs usage there might have been less records of type $\mathrm{V}$ ulcer perforation localizations in this study.

Before the invention of PPI vagotomy and partial gastric resections were considered to be the main surgical treatment option for PPU, but these days mentioned approaches became not so common [6]. Although laparotomy with simple closure of perforation site is considered to be the standard management at this time, numbers of laparoscopic approach are increasing with rates of 30-45\% [2] For recent perforations (up to 6 hours) it is standard in our hospital to perform laparoscopic simple closure in young patients. Nevertheless, if the peritonitis is clinically severe an open approach might be chosen. In order to compete with other countries we could perform more laparoscopic surgeries for PPU.

Overall PPU mortality rate is 3-30\% [2]. If PPU is diagnosed and handled in a short period of time, mortality ranges from $6 \%$ to $14 \%$. Higher mortality rate is associated with delayed diagnosis and treatment, older age of the patients and comorbidities [15]. In our study most of the patients were elderly with other medical illnesses thus resulting in overall mortality rate of $24 \%$. (picture 2)

Surgical treatment method and approach did not correlate with the outcome, demonstrating that laparoscopic approach is equally safe and effective as open approach.

It has been estimated that Mannheim Peritonitis Index (MPI) has $77.2 \%$ accuracy of predicting mortality in patients with PPU [16]. We observed statistically significant correlation between Mannheim Peritonitis Index and outcomes, suggesting that higher MPI increases chance of worse outcomes.

\section{Conclusions}

During the period from 2015 to 201790 patients were treated for PPU. Half of the patients had type II ulcer localization according to modified Johnson classification. Simple closure was performed for $91 \%$ of the patients, $84 \%$ of all surgeries were performed with an open approach. Statis- 
tically significant correlation was found between Mannheim Peritonitis Index and mortality, age and mortality and between age and Mannheim Peritonitis Index. No significant correlation was observed between the approach and the outcome.

There should be a bigger role in laparascopic surgery treating PPU, which we should consider in our clinical approach of our department.

It is important for clinicists to consider about PPI for treatment when prescribing NSAIDs, especially in elderly and hospitalized patients in order to avoid peptic ulcers and its complications.

Conflict of interest: none.

\section{References}

1. Lau JY, Sung J, Hill C, Henderson C, Howden CW, Metz DC. Systematic review of the epidemiology of complicated peptic ulcer disease: incidence, recurrence, risk factors and mortality. Digestion 2011; 84(2):102-13.

https://doi.org/10.1159/000323958

2. Kjetil Søreide, Kenneth Thorsen, Ewen M. Harrison, Juliane Bingener, Morten H. Møller, Michael Ohene-Yeboah, Jon Arne Søreide, Perforated peptic ulcer. Lancet 2015 Sep 26; 386(10000):1288-1298.

https://doi.org/10.1016/S0140-6736(15)00276-7

3. Gisbert JP, Legido J, García-Sanz I, Pajares JM. Helicobacter pylori and perforated peptic ulcer prevalence of the infection and role of non-steroidal anti-inflammatory drugs. Dig Liver Dis $2004 \mathrm{Feb} ; 36(2): 116-20$.

https://doi.org/10.1016/j.dld.2003.10.011

4. Wang YR, Richter JE, Dempsey DT. Trends and outcomes of hospitalizations for peptic ulcer disease in the United States, 1993 to 2006. Ann Surg 2010 Jan;251(1):51-8.

https://doi.org/10.1097/SLA.0b013e3181b975b8

5. Kin Tong Chung and Vishalkumar G Shelat. Perforated peptic ulcer - an update. World J Gastrointest Surg 2017 Jan 27; 9(1): $1-12$.

https://doi.org/10.4240/wjgs.v9.i1.1

6. K. Søreide, K. Thorsen, J. A. Søreide. Strategies to improve the outcome of emergency surgery for perforated peptic ulcer. Br J Surg 2014 Jan;101(1):e51-64.

https://doi.org/10.1002/bjs. 9368

7. Lin BC, Liao CH, Wang SY, Hwang TL. Laparoscopic repair of perforated peptic ulcer: simple closure versus omentopexy. J Surg Res 2017 Dec;220:341-345.

https://doi.org/10.1016/j.jss.2017.07.034

8. Abd Ellatif ME, Salama AF, Elezaby AF, El-Kaffas HF, Hassan A, Magdy A, Abdallah E, El-Morsy G. Laparoscopic repair of perforated peptic ulcer: patch versus simple closure. Int J Surg 2013;11(9):948-51.

https://doi.org/10.1016/j.ijsu.2013.06.014
9. Smith RS, Sundaramurthy SR, Croagh D. Laparoscopic versus open repair of perforated peptic ulcer: A retrospective cohort study. Asian J Endosc Surg 2018 May 27.

https://doi.org/10.1111/ases. 12600

10. Naesgaard JM, Edwin B, Reiertsen O, Trondsen E, Faerden AE, Rosseland AR. Laparoscopic and open operation in patients with perforated peptic ulcer. Eur J Surg 1999 Mar;165(3):20914.

https://doi.org/10.1080/110241599750007063

11. Thorsen K, Søreide JA, Kvaløy JT, Glomsaker T, Søreide K. Epidemiology of perforated peptic ulcer: age- and gender-adjusted analysis of incidence and mortality. World J Gastroenterol 2013 Jan 21; 19(3): 347-354.

https://doi.org/10.3748/wjg.v19.i3.347

12. Rigopoulos A, Ramboiu S, and Georgescu I. A critical evaluation of surgical treatment of perforated ulcer. Curr Health Sci J 2011 Apr-Jun; 37(2): 75-78.

https://www.ncbi.nlm.nih.gov/pmc/articles/PMC3994673/

13. Girish S. Noola, Shivakumar C. R. A clinical study of duodenal ulcer perforation. Int Surg J 2016 May;3(2):711-713.

http://dx.doi.org/10.18203/2349-2902.isj20160457

14. Kumar D, Shahil P. Perforated peptic ulcer \& its association with vascular anatomy of stomach \& duodenum. IOSR Journal of Dental and Medical Sciences 2017 May;16(5):16-18.

https://doi.org/10.9790/0853-1605041618

15. Di Saverio S, Bassi M, Smerieri N, Masetti M. et al. Diagnosis and treatment of perforated or bleeding peptic ulcers: 2013 WSES position paper. World J Emerg Surg 2014 Aug 3;9:45. https://doi.org/10.1186/1749-7922-9-45

16. Anbalakan K, Chua D, Pandya GJ, Shelat VG. Five year experience in management of perforated peptic ulcer and validation of common mortality risk prediction models - are existing models sufficient? A retrospective cohort study. Int J Surg 2015 Feb;14:38-44.

https://doi.org/10.1016/j.jisu.2014.12.022

\section{PEPSINIU OPU PERFORACIJOS: 3 METU PATIRTIS KLAIPE்DOS UNIVERSITETINĖJE LIGONINĖJE \\ Š.Dailidėnas, M.Garčauskis, G.Srèbaliūtė, J.Jurgaitis, P.Žeromskas, D.Šimčikas}

Raktažodžiai: perforuota pepsinè opa.

Santrauka

Perforacija yra antra dažniausia pepsinių opų komplikacija. Mirštamumas nuo pepsinių opų perforacijos siekia 3-30 \%. Perforacijos turi būti diagnozuojamos ir gydomos kuo greičiau, norint išvengti prastų baigčių.

Tikslai ir metodai. Tyrimo tikslas buvo pateikti mūsų klinikinę patirtị gydant pacientus su perforuota pepsine opa. Atlikta pacientų, gydytų dèl perforuotos pepsinès opos Klaipėdos universitetinèje ligoninejje nuo 2015 iki 2017 metų, duomenų retrospektyvinè analizè. Statistiné analizè atlikta naudojant SPSS 20.0 sta- 
tistinès analizès paketą.

Rezultatai. 90 pacientų buvo gydomi dèl perforuotos pepsinès opos. Moterų ir vyrų santykis buvo 1:1,25, vidutinis amžius $61,60 \pm 19,42$ metų. Tolimesnių duomenų iš 16 pacientų nebuvo. Vidutinis lovadienių skaičius buvo $12.89 \pm 13.31$ dienų. $11 \%$ pacientų buvo nustatyta I tipo, 49 \% - II tipo, 24 \% - III tipo, 5 \% - IV tipo, $11 \%$ - V tipo opa pagal modifikuotą Johnson klasifikaciją. $91 \%$ pacientų buvo atliktas opos užsiuvimas, $4 \%$ - Billroth I tipo, $2 \%$ - Billtorth II tipo operacijos, $1 \%$ atlikta atipinè rezekcija. 84 $\%$ operacijų buvo atliekamos atviru būdu, $12 \%$ - laparoskopiškai, $4 \%$ atlikta konversija. Vidutinis operacijos laikas buvo $85,2 \pm 4,64$ minutès, vidutinis Mannheimo Peritonito Indeksas - 17,135 7,36. $24 \%$ pacientų mirè. Nustatyta statistiškai reikšminga koreliacija tarp Mannheimo Peritonito Indekso ir mirštamumo $(r=0,640 ; p<0,05)$, tarp amžiaus ir mirštamumo $(\mathrm{r}=0,459 ; \mathrm{p}<0,05)$, bei tarp amžiaus ir Mannheimo Peritonito Indekso $(r=0,740 ; p<0,05)$.

Išvada. Nuo 2015 iki 2017 metų 90 pacientų buvo gydomi dèl perforuotos pepsinès opos. Pusei pacientų buvo nustatyta II tipo opa pagal modifikuotą Johnson klasifikaciją. Opos užsiuvimas buvo taikytas $91 \%$ pacientų, $84 \%$ visų operacijų atlikta atviru būdu. Statistiškai reikšminga koreliacija nustatyta tarp Mannheimo Peritonito Indekso ir mirštamumo, amžiaus ir mirštamumo bei tarp amžiaus ir Mannheimo Peritonito Indekso. Statistiškai reikšminga koreliacija tarp operacijos būdo ir baigčių nustatyta nebuvo. Laparoskopinè chirurgija turètų turèti didesnị vaidmenį gydant perforuotas pepsines opas, $\mathfrak{i}$ tai turètų atsižvelgti mūsų klinika. Norint išvengti pepsinių opų ir jų komplikacijų, ypatingai vyresnio amžiaus ar hospitalizuotiems pacientams, svarbu, jog gydytojas apsvarstytų protonų siurblio inhibitorių skirimą kartu su NVNU.

Adresas susirašinèti: sarudaili@gmail.com

Gauta 2019-03-01 